Neurolmages
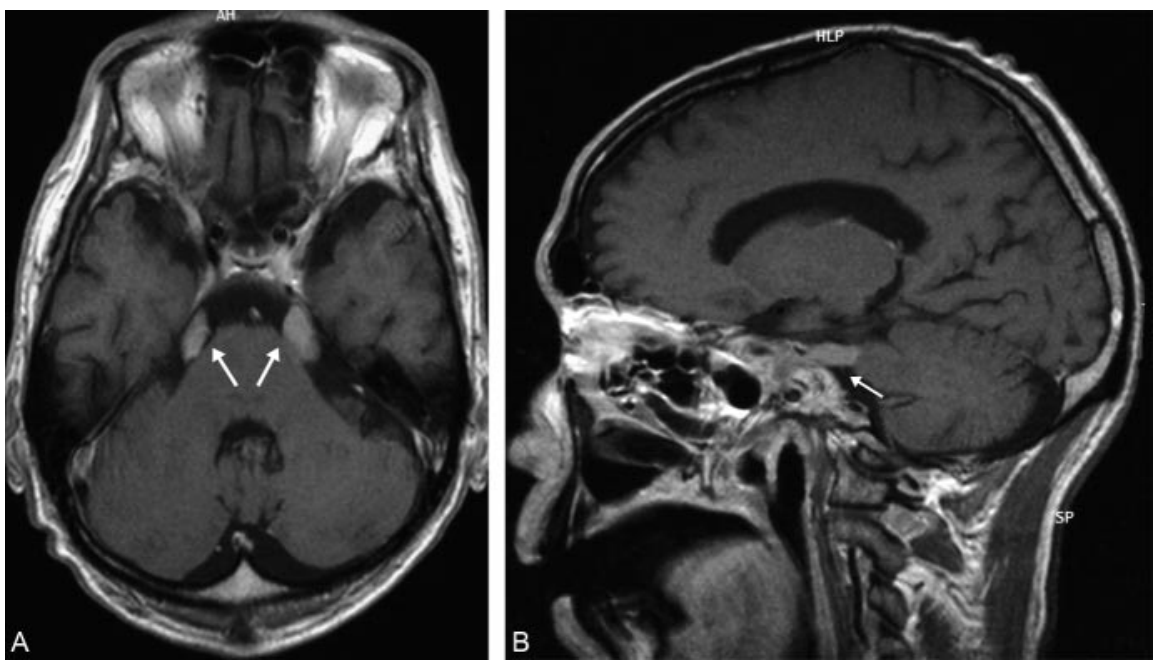

Figure. Gadolinium-enhanced axial and sagittal T1-weighted images of the brain of a patient with long-term CIDP, showing bilateral nerve root hypertrophy of the trigeminal nerves.

\section{Hypertrophic cranial nerve roots in CIDP}

H. Inoue, MD; Y. Tsuboi, MD; J. Tsugawa, MD; F. Fujiki, MD; and T. Yamada, MD, Fukuoka, Japan

A 61-year-old man presented with painful dysesthesia/dysarthria (3 months) and sensorimotor impairment (13 years). Chronic inflammatory demyelinating polyradiculoneuritis (CIDP) was confirmed 4 years earlier by electrophysiological study and sural nerve biopsy. Examination revealed extremity atrophy, cranial nerve involvement (bilateral ophthalmoparesis, facial palsy, and

Address correspondence and reprint requests to Dr. Yoshio Tsuboi, Department of Neurology, Fukuoka University School of Medicine, 7-45-1 Nanakuma, Johnan-ku, Fukuoka, Japan 814-0180; e-mail: tsuboi@cis.fukuoka-u. ac.jp. tongue atrophy), absent deep tendon reflexes, impaired deep sensation, preserved superficial sensation, and impalpable peripheral nerves.

MRI demonstrated bilateral nerve root hypertrophy of the oculomotor, trigeminal (figure), abductor, and facial nerves, illustrating the relationship between long-term CIDP and nerve root hypertrophy..$^{1-2}$ Long-term CIDP should be considered in the differential diagnosis of cranial nerve hypertrophy.

1. Guibord N, Chalk C, Wein F, Richardson J, Snipes GJ, Del Carpio R. Trigeminal nerve hypertrophy in chronic inflammatory demyelinating polyradiculoneuropathy. Neurology 1998;51:1459-1462.

2. Schady W, Goulding PJ, Lecky BR, King RH, Smith CM. Massive nerve root enlargement in chronic inflammatory demyelinating polyneuropathy. J Neurol Neurosurg Psychiatry 1996;61:636-640. 


\title{
Neurology
}

\author{
Hypertrophic cranial nerve roots in CIDP \\ H. Inoue, Y. Tsuboi, J. Tsugawa, et al. \\ Neurology 2004;63;1481 \\ DOI 10.1212/01.WNL.0000137033.77605.B2
}

This information is current as of October 25, 2004

\section{Updated Information \& Services}

References

Citations

Subspecialty Collections

Permissions \& Licensing

Reprints including high resolution figures, can be found at: http://n.neurology.org/content/63/8/1481.full

This article cites 2 articles, 2 of which you can access for free at: http://n.neurology.org/content/63/8/1481.full\#ref-list-1

This article has been cited by 4 HighWire-hosted articles: http://n.neurology.org/content/63/8/1481.full\#\#otherarticles

This article, along with others on similar topics, appears in the following collection(s):

MRI

http://n.neurology.org/cgi/collection/mri

Peripheral neuropathy

http://n.neurology.org/cgi/collection/peripheral_neuropathy

Information about reproducing this article in parts (figures,tables) or in its entirety can be found online at:

http://www.neurology.org/about/about_the_journal\#permissions

Information about ordering reprints can be found online:

http://n.neurology.org/subscribers/advertise

Neurology ${ }^{\circledR}$ is the official journal of the American Academy of Neurology. Published continuously since 1951, it is now a weekly with 48 issues per year. Copyright . All rights reserved. Print ISSN: 0028-3878. Online ISSN: 1526-632X.

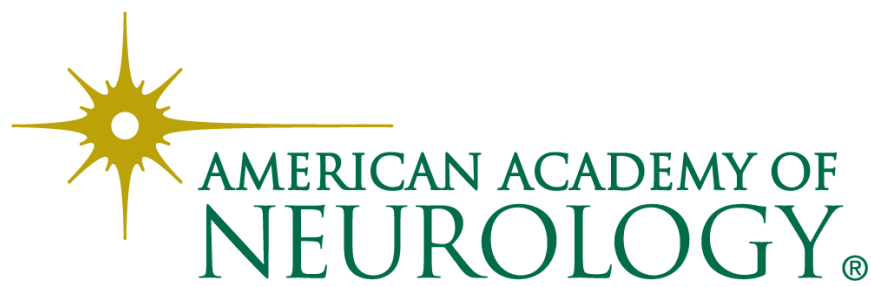

